\title{
MENCERMATI IDEOLOGI FIKIH POLITIK GERAKAN FUNDAMENTALISME IKHWAN AL MUSLIMIN DI MESIR
}

\section{Roibin}

Fakultas Syari'ah Universitas Islam Negeri Maulana Malik Ibrahim Malang. Jl. Gajayana No 50 Malang, Telp. (0341) 551354, Hp.08179604562. e-mail:roibinuin@gmail.com

\section{Abstract}

The paper discusses the ideology of fundamentalism on political figh. Their idea of 'total Islam' emerges problematic situation as the concept they build has not yet faced theoretical and practical construction. This is in line with the idea they have, historical-philology, a kind of paragidm which trying to have religious comprehension structurally, textually, and literally. Since its establishment in 1981, Ikhwan community has conducted many political activities. All activities are intended to reach the vision and mission of the organization, even, by conducting an extreme way that is executing the leader who does not response and accomodate their belief, syari'at Islam. This situation leads to a point of view that their movement is successful and fail in two different sides. They successfully defend the consistency to build the religious proselytizing activities. On the other hand, they cannot have any support from the leader to accomodate their activities.

Key words: idealogy, political activity, and fundamentalism

Ulul Albab, Vol. 10, No. 1, 2009 


\section{Pendahuluan}

Paradigma "Islam totalitas" sebagai idiologi keagamaan yang dikonsepsikan oleh para aktivis Islam fundamentalis dalam realitasnya menyisakan berbagai persoalan problematis. Dikatakan demikian, karena konsep yang dibangun oleh kelompok tersebutbelum mampu mempertemukan konstruksi teoretis (normatif-doktriner) dan praktis (historis). Pada satu sisi paradigma ini telah berusaha mencari makna asli dari penjelasan suatu teks keagamaan dengan pendekatan historiko-filologis (Martin, 1985: 8), suatu pendekatan yang menampakkan karakter pemahaman keagamaan secara struktural, tekstual dan literal.

Di sisi lain kelompok Islam fundamentalis ini kurang berusaha mencari makna holistik dibalik realitas simbolik perilaku keberagamaan yang tampak dalam komunitas masyarakat dengan pendekatan historis, diakronik sinkronik (Martin, 1985: 8). Model pemahaman yang seringkali menampakkan karakteristik pemahaman keagamaan secara kontekstual, yaitu pemahaman keagamaan yang tidak menghindari konstruk sosio-kultural yang melingkupinya. Agama dalam pemahaman yang kedua ini tidak dipandang sebagai paket Tuhan yang hampa sejarah, yang sulit diperdebatkan, oleh suatu komunitas yang hidup pada era tertentu dan kondisi tertentu. Lebih dari itu agama dianggap sebagai organisme yang hidup dan berkembang sesuai dengan denyut nadi perkembangan peradaban manusia (Abdalla, 2003: 3).

Secara teoretis, Islam ideal perspektif fundamentalis dipersepsi sebagai suatu institusi keagamaan yang sanggup menjawab beragam problem dan tantangan kemanusiaan secara global, baik dalam ranah sosial budaya maupun sosial politik. Merupakan pemikiran yang salah jika Islam hanya diposisikan pada dimensi ruhaniah dan ibadah saja. Lebih luas lagi, kelompok ini mengatakan bahwa Islam meliputi doktrin, penyembahan, tanah air, agama, kebangsaan keruhaniahan dan pedang. Antara agama dan persoalanpersoalan sosial-politik merupakan instrumen keislaman yang tidak bisa dipisahkan dan didikotomikan.

Sikap optimistik kerangka paradigmatika ideologi keagamaan kelompok Islam fundamentalis ini, pada satu sisi telah membawa Islam 
berada pada puncak kejayaannya. Namun pada sisi lain gerakan Islam fundamentalis ini, utamanya di Mesir tidak sedikit telah menunjukkan usaha-usaha kegagalannya. Lebih jelas, indikasi kegagalan perjuangan Islam fundamentalis di Mesir itu, terutama terlihat ketika mereka berhadapan dengan para penguasa pemerintahan. Tidak ada satu pun program mereka yang bisa terakomodir di kalangan penguasa pemerintahan ketika itu, bahkan dalam kenyataannya perjuangan mereka selalu berhadapan dengan penguasa pemerintahan.

Mengapa cita-cita ideal yang terakumulasi dalam "Islam totalitas" sebagai sebuah ideologi keagamaan senantiasa menyisakan persoalanpersoalan baru, yaitu mengalami kegagalan dalam realitasnya? Mengapa pula konsep ideal mereka hanya bertengger dalam tataran teoretis belaka? Mengapa konsep tersebut tidak mampu tersosialisasi dalam bumi realitas? Adakah faktor-faktor penyebabnya? Atas dasar pemikiran di atas, makalah ini akan menjawab berbagai persoalan tersebut dengan pendekatan sosiohistoris. Dari beberapa persoalan di atas akan diajukan beberapa pertanyaan dengan sistematika sebagai berikut: 1). Apa dan bagaimana idiologi gerakan ini? 2). Apa yang melatarbelakangi munculnya gerakan ini? Landasan teori apa yang bisa dijadikan sebagai pisau analisis pembacaan gerakan ini? 3). Untuk mengawali kajian tersebut dalam makalah ini akan dikaji sekilas seputar fundamentalisme secara umum.

Diskursus tentang fundamentalisme sampai saat ini, menurut Roger Garaudy masih berada dalam bingkai penafsiran yang berkonotasi pejorative (Sahat, 1993: 150). Sebagian pemikir ada yang beranggapan bahwa fundamentalisme merupakan ekspresi kultus keagamaan yang berakar pada alienasi dan dislokasi sosial di tengah laju modernisasi. Sebagian yang lain mengatakan ia merupakan gejala patologi keagamaan (Sahat, 1993: 150). Namun demikian pandangan seperti ini menurut Garaudy terkesan bernada berat sebelah, karena fundamentalisme semata-mata hanya diposisikan sebagai gerakan reaksioner keagamaan, di mana imbas dari nilai-nilai negatif modernisasi telah dituding sebagai faktor penyebab sosialnya. Dengan begitu, fundamentalisme pada ranah keagamaan tidaklah 
monolitik dalam sebab dan karakteristiknya. Lebih dari itu ia bukan hanya monopoli agama, melainkan telah menggejala pada lingkup budaya dan pentas politik. Bahkan akar persoalan fundamentalisme itu pada hakikatnya tidak saja berada pada aras teologis, melainkan juga pada arus modernitas, yang konon ternyata mengandung beberapa unsur fundamentalisme itu juga. Dengan kata lain, kalau seandainya terdapat kecenderungan fanatis reaksioner dalam fundamentalisme agama, itu semua tidak lain merupakan jawaban ekstrem melawan fundamentalisme Barat yang tidak kalah tingkat ekstrimisnya (Tibi, 1998: 5-6).

Garaudy mencoba melihat fundamentalisıne dalam satuan analisis yang lebih luas. Fundamentalisme dipahami sebagai suatu pandangan yang ditegakkan atas keyakinan baik bersifat agama, politik maupun sosial-budaya. Jika fundamentalisme di atas dikaitkan dengan Islam maka fundamentalisme Islam berarti suatu pandangan yang ditegakkan atas dasar kerangka keyakinan Islam, baik dari dimensi agama, politik maupun sosio-kulturalnya.

\section{Fundamentalisme Islam Ikhwan al Muslimin dan Kecenderungan Ideologinya}

Sesuai dengan maknanya, Fundamentalisme Islam adalah suatu pandangan yang ditegakkan atas kerangka keyakinan lslam secara total melalui berbagai dimensi apa pun. Fundamentalisme Islam berarti sebuah idiologi keagamaan yang menegaskan bahwa Islam adalah totalitas kehidupan. Islam harus diformulasi sebagai suatu institusi keagamaan yang mampu menjawab baragam problema dan tantangan kemanusiaan secara global, baik dalam dimensi sosial-budaya maupun sosiol politik. Dalam pemahaman seperti ini tampaknya gejala fundamentalisme Islam sulit dipisahkan dari aktifitas politiknya. Lebih-lebih dalam realitas kesejarahan, aktifitas politik kelompok fundamentalisme Islam ini memang sangat tampak sekali.

Untuk membuktikan kebenaran pandangan di atas serta arah gerakan idiologinya bisa kita lihat misalnya pada munculnya beberapa gerakan Islam, seperti Jamaah Islami di Pakistan, Front Penyelamat Islam di Aljazair, al Ikhwan al Muslimin di Mesir. Sementara gerakan serupa juga muncul di 
Indonesia dengan bentuk konkritnya melalui spektrum perpolitikan yang berusaha untuk memasukkan nilai-nilai Islam dalam undang-undang. Dengan kata lain perilaku dan karakteristik gerakan seperti ini telah menunjukkan adanya suatu keinginan untuk menerapkan shari' ah ke dalam sistem kehidupan kenegaraan.

Pandangan ini di mata Imam Hasan al Banna sangatlah tepat dan jelas. Hal demikian bisa kita lihat ketika Imam Hasan al Banna memberikan jawaban atas berbagai kritik yang dilontarkan oleh banyak pihak. Antara lain kritik yang mengatakan bahwa Ikhwan adalah para politikus, dakwah Ikhwan adalah dakwah politik, demikian juga Ikhwan memiliki tujuan-tujuan lain di balik semua sepak terjangnya. Tentang anggapan ini ia mengatakan "Wahai bangsa kami, kami menyeru kalian kepada Islam, ajaran-ajaran Islam, dan hukum-hukum Islam. Jika menurut kalian ini semua adalah bagian dari politik, maka inilah politik kami. Jika kalian hendak menamai semua ini sebagai kegiatan politik, silahkan katakan-sekehendak kalian. Bagi kami nama apapun bukan masalah, jika substansinya jelas dan telah dipahami" (ath Tahhan, 2000: 46).

Masih menurutnya, jika ditanyakan kepada kalian, kepada apakah kalian menyeru? Jawablah, kami menyeru kepada Islam yang telah dibawa oleh Muhammad, dan pemerintahan adalah bagian darinya, sedangkan kebebasan adalah di antara salah satu dari tuntutannya. Jika dikatakan kepada kalian bahwa hal itu adalah politik, katakanlah bahwa itu adalah lslam, dan kami tidak mengenal dikotomi itu (Hasan al Banna, Tt: 31).

Sebagaimana Hasan al Banna, ia juga menjelaskan bahwa seorang muslim tidak sempurna keislamannya kecuali jika ia menjadi seorang politikus, berpandangan jauh tentang persoalan bangsanya.

Dari pandangan pendiri gerakan Islam di atas telah menunjukkan adanya hubungañ yang dekat bahkan tidak bisa dipisahkan antara agama dan kegiatan politiknya. Mengingat Islam-menurut kaúm Islam fundamentalissulit dipisahkan dari kegiatan politiknya, mengingat garis idiologi yang mereka bangun pada hakikatnya adalah pandangan yäng ingin menghadirkan 
sebuah negara dan penegakan syari'ah Islam. Inilah sebabnya di kalangan Islam fundamentalis memiliki keyakinan bahwa islam harus menjadi suatu kerangka teoretis yang bisa dijadikan sebagai solusi bagi setiap problem umat (Mutawalli, 2003: 42).

Islam harus mampu memperbarui penampilannya sebagai sumber ilham di dalam konteks proses masyarakat yang hendak menjadi modern. Sebab kalau tidak, dikhawatirkan momentum, di mana sekali lagi agama akan tampil sebagai sumber ilham akan lewat (Amin, 1993: 4). Agama harus berani menyuarakan hati nurani umatnya. Lebih jauh dari itu, seorang sosiolog Daniel Bell mengatakan bahwa letak kekuatan agama adalah pada kemampuannya untuk melakukan responsi secara moral (Ulumul Quran, 1998: 70). Dalam menjalankan tugasnya ini agama harus didukung oleh kekuatan budaya yang ada (Ulumul Quran, 1998: 70). Dengan demikian agama akan memainkan peranan transformatifnya, sebagaimana awal kelahirannya.

\section{Faktor Penyebab Munculnya Gerakan Politik Ikhwan al Muslimin di Mesir}

Gerakan al Ikhwan al Muslimun yang akrab dengan sebutan Ikhwan, bukanlah gerakan yang terlepas dari akar idiologis gerakan-gerakan Islam sebelumnya. Namun gerakan tersebut merupakan suatu gerakan Islam yang telah mengakar kuat dalam sejarah Islam, utamanya Islam di Mesir (Harun Nasution: 250). Di antara gerakan yang cukup berpengaruh yang muncul sebelum kelahiran Ikhwan adalah gerakan Jama'atu al Syubban al Muslimin (Himpunan Pemuda Islam) yang didirikan pada tahun 1927, dimana Hasan al Banna dalam gerakan itu merupakan seorang yang cukup berperan dan aktif. Baru kemudian pada tahun 1928 Imam Hasan al Banna secara resmi mendirikan apa yang akan menjadi perhimpunan lebih besar, yaitu jama'atu al Ikhwan al Muslimin (Perhimpunan Persaudaraan Muslim).

Gerakan Ikhwan ini pada prinsipnya muncul sebagai reaksi terhadap kemerdekaan di Mesir pada tahun 1921 yang bersifat sangat sekuler. Akibat dari pemerintahan sekuler itu, Syari'at Islam secara perlahan telah tergeser

Ulul Albab, Vol. 10, No. 1, 2009 
peran dan fungsinya. Hal-hal yang menyangkut tentang keperdataan saja, seperti perkawinan dan perceraian yang diatur oleh shari'ah Islam, sementara beberapa aspek lainnya diatur dan ditata dengan melalui undang-undang sekuler. Kenyataan inilah yang banyak mendorong gerakan Ikhwan untuk menjunjung tinggi supremasi shari'ah Islam dan memberantas kemadlaratan yang diakibatkan, baik langsung maupun tidak langsung oleh pemerintahan sekuler yang dinilai banyak bertentangan dan melanggar shari'ah tersebut (Mujahidin, 2003: 15).

Munculnya gerakan ini tidak bisa lepas dari dukungan moral berbagai kalangan. Kalangan másyarakat yang memiliki kontribusi bagi munculnya gerakan itu adalah kalangan pemuka agama, para tokoh tarekat dan tasawuf, para tokoh masyarakat dan para pengunjung klub/perkumpulan organisasi. Berkat kecerdasan, kesungguhan dan kepiawaian Hasan al Banna yang menjalin komunikasi dengan masing-masing lapisan tersebut, telah menarik minat mereka bergabung dengan al Banna. Dengan senang hati Hasan alBanna menyambut niat baik mereka itu dan segera al Banna mengusulkan nama kelompk tersebut dengan al Ikhwan al Muslimun.

Gerakan ini pada mulanya identik dengan organisasi sosial yang lainnya, namun pada perkembangannya, ia menjadi gerakan yang memiliki kekuatan politik yang tangguh. Hal ini antara lain disebabkan oleh orientasi dan kerangka idiologis yang dibangun di atas panji-panji al Quran dan al Sunnah secara ketat dan rigid di tengah kehidupan umat (Hino, 1989: 63). Melalui doktrin-doktrin dari ajaran ini, mereka memiliki komitmen terhadap ajaran Islam totalitas. Bagi Hasan al Banna, suatu pandangan yang menyatakan bahwa Islam hanya respon pada aspek ruhaniah dan ibadah saja merupakan pandangan yäng sangat salah. Secara spesifik ia mengatakan bahwa Islam itu meliputi doktrin, penyembahan, tanah air, agama, kebangsaan, keruhaniahan dan pedang (al Husaini, 1984: 9).

Pernyataan al Banna di atas, setelah ditelaah secara detil memang tidak bisa lepas dari kerangka pemikiran radikal dan revolusioner pemikiran politik al Maududi yang secara lebih spesifik telah diformulasikan oleh Sayyid Qutub melalui karyanya yang berjudul Ma'alim fi al Tharic. Dari pemikiran politik 
kedua tokoh inilah al Banna berhasil mengkomparasikan pemikiran dan idiologinya, yang pada gilirannya dijadikan dasar untuk merumuskan prinsipprinsip perjuangan Ikhwan yang terdiri atas enam prinsip. Pertama: ilmiah, yaitu menjelaskan al Quran secara tepat melalui tafsir asli dan segala elemen universalnya, melengkapinya dengan semangat zaman, membelanya dari kepalsuan dan kesangsian. Kedua: praktek, yaitu pembangunan masyarakat Islam seutuhnya di atas suatu dasar keagamaan dan penyelesaian perbedaan di antara berbagai madzhab. Ketiga: ekonomi, yaitu peningkatan kesejahteraan, keadilan, dan keamanan semua warga. Keempat: sosio-filantropis, yaitu meningkatkan pelayanan masyarakat, pendidikan, kesehatan dan amar makruf nahi munkar. Kelima: patriotisme dan nasionalisme. Keenam: Kemanusiaan dan universalisme, yaitu mengusahakan kehidupan yang lebih manusiawi atas dasar ajaran Islam (al Husaini, 1984: 9). Terhadap keenam prinsip ini lkhwan berusaha mengaplikasikannya sebagai dasar filofisnya. Dengan kata lain gerakan ini berupaya untuk menegakkan keagungan Islam dalam berbagai aspek kehidupan. Dengan demikian gerakan Ikhwan bisa diartikan sebagai gerakan yang berlabelkan Islam, bersyi'arkan Islam, serta menjadikan Islam sebagai dasar filosofis dan tujuan ideal dari gerakannya. Meskipun di kemudian hari gerakan Ikhwan al Muslimin yang disemangati oleh dua pemikiran yang sangat radikal itu al Maududi dan Sayyid al Qutub telah terbelah menjadi kelompok formal (militan) dan kelompok informal (mutadayyinin)

Belum genap satu tahun sejak pindahnya Ikhwan al Muslimin ke Kairo (1932) akibat gigihnya aktivitas dakwah gerakan Ikhwan tersebut Imam Hasan telah berhasil menyebarkan dakwah ke seluruh lbu kota Mesir. Ia juga membuka beberapa cabang lebih dari lima puluh cabang di kota besar maupun kecil. Sejak itulah kota-kota Mesir telah dipadati oleh gerakan da'i Ikhwan al-muslimin. Salah satu cara efektif untuk mensosialisasikan misi dan tujuannya, gerakan Ikhwan berusaha menembus mas media. Pada tahun yang sama, Ikhwan menyelenggarakan muktamar pertama dan musyawarah nasional. Kegiatan serupa itu diselenggarakan secara intensif dari tahun ke tahun hingga tahun 1941 (Mahmud, 1997: 30-36). 
Kegiatan-kegiatan itu secara pereodik mengalami perkembangan sistematis. Lebih spesifik lagi pada tảhun 1942-1948 kegiatan Ikhwan lebih dikonsentrasikan pada teknis dan setrategi politik (Mahmud, 1997: 36-44). Tahun 1948 adalah tahun yang sangat bersejarah bagi gerakan Ikhwan, mengingat tahun itu adalah tahun di mana gerakan Ikhwan terlibatlangsung dalam perang Arab-lsrael I. Dalam peristiwa itu gerakan lkhwan banyak berinteraksi dengan pasukan Mesir dan Palestina (Sihbudi, 1991: 8).

Berawal dari peristiwa ini pula semangat serta keberanian kelompok gerakan Ikhwan semakin kuat. Hanya saja bersamaan dengan moment itu, raja Farouk telah berusaha membubarkan Ikhwan dan menahan sejumlah besar tokoh-tokohnya kecuali Hasan al-Banna. Dan yang paling tragis lagi dari moment itu adalah terjadinya dua peristiwa pembunuhan yang membuat gerakan Ikhwan .sebagai gerakan yang anti Establishment (Sihbudi, 1991: 8).

Pembunuhan terhadap Perdana Menteri Nuqrashi Pasha, yang dilakukan oleh seorang anggota Ikhwan. Kedua: pembunuhan terhadap Hasan al-Banna yang dilakukan oleh polisi kerajaan Mesir (Sihbudi, 1991: 8). Dari pembacaan peristiwa yang terakhir ini kita pahami bersama bahwa telah terdapat krisis kepercayaan, hingga menimbulkan saling curiga akibat kekhawatiran timbulnya penggulingan kekuasaan yang akan dilakukan oleh salah satu di antara kedua pihak. Fenomena peristiwa pembunuhan antara dua kelompok sebagaimana yang kita pahami di atas, kurang memberikan kontribusi signifikan bagi dua kelompok di atas.

Tahun 1952, Ikhwan memberikan dukungan sepenuhnya kepada Jamal Abdul Nasser dalam upayanya melancarkan revolusi yang meruntuhkan kekuasaan raja Farouk. Hal itu dilakukan, dengan harapan Ikhwan hendak menjalin kerjasama dengan Nasser. Keinginan Ikhwan ternyata tidak semulus dengan niat yang telah dibangunnya, bahkan kenyataan yang terjadi justru sebaliknya, kenyataan itu mulai terasa dikalangan kelompok Ikhwan pada tahun 1954-1970-an. Ternyata dibalik itu semua rezim Nasser telah merancang usaha untuk menghancurkan gerakan lkhwan. Banyak tokohtokoh Ikhwan yang dihukum mati oleh rezim Nasser. Sebut saja misalnya 
Sayyid Qutub salah seorang ideolog Ikhwan pada tahun 1965 telah dihukum mati oleh rezim Nasser. Meski demikian tidak berarti eksistensi gerakan lkhwan telah lenyap, bahkan di beberapa negara Arab seperti di Libya dan Suriah pengaruh Ikhwan semakin kental (Azra, 1996: 116 dan Jamilah, 1993: 148). Rentang waktu antara tahun 1952.1965 merupakan momentum yang berat dan sangat memprihatinkan bagi Ikhwan.

Perjuangan Ikhwan tampak lebih parah lagi ketika rezim Nasser telah digantikan oleh Anwar Sadat pada tahun 1970-1981. Sebuah rezim yang menjunjung tinggi nilai-nilai liberalisasi clan sekularisasi pada semua aspeknya. Rezim yang telah berhasil mengubah alam Mesir menjadi pro kepada Barat, utamanya Amerika Serikat. Kenyataan inilah yang secara khusus banyak mendorong gerakan Ikhwan untuk melakukan gerakan-gerakan oposan terhadap penguasa yang telah dianggap sekuler. Tradisi demonstrasi sejak itu sudah mulai menggejala di kalangan kelompok Ikhwan mulai dari bentuk demonstrasi yang bersekala lokal hingga nasional. Sayangnya gerakan yang dilakukan olch Ikhwan ini berakhir dengan adanya suatu tuduhan, bahwa mereka dianggap telah terlibat merencanakan pembunuhan tethadap Sadat. Mereka semua itu oleh penguasa dianggap sebagai kelompok jihad yang akan merebut kekuasaan dengan jalan kekerasan.

Aktifitas kelompok Ikhwan yang kerap disebut sebagai kelompok fundamentalisme Islam ini tidak terlalu berbeda jauh dengan aktifitas yang dikemas pada rezim setelahnya. Pada rezim ini (Husni Mubarak) rezim yang secara resmi dan konstitusi telah menggantikan Anwar Sadat agenda menonjol yang diperjuangkan oleh kelompok Ikhwan adalah menuntur diberlakukannya hukum Islam dan demonstrasi di beberapa kampus yang mengecam Israel dan AS sehubungan dengan penyergapan pesawat sipil Mesir tahun 1985.

Elaborasi di atas secara jelas telah menggambarkan bahwa kelompok Ikhwan sejak berdirinya hingga tahun 1981 selalu sarat dengan berbagai kegiatan politis. Semua kegiatan itu dimaksudkan untuk mencapai misi dan visi organisasinya. Namun demikian demi mencapai tujuan prinsip dari organisasinya, kadang gerakan Ikhwan tidak segan-segan untuk melakukan

Ulul Albab, Vol. 10, No. 1, 2009 
sikap kekerasan terhadap penguasa yang dianggap tidak merespon dan mengakomodasi kepentingan prinsip organisasinya, yaitu menerapkan syari'at islam. Bila diamati secara saksama kegiatan dakwah gerakan Ikhwan ini bisa dinilai sukses disatu sisi, dan gagal di sisi yang lain. Sukses karena kegigihan dan konsistensinya menegakkan aktifitas dakwah, sementara gagal karena tidak satupun penguasa pada masanya yang mengakomodasi kegiatan dakwah mereka. Dua persoalan inilah yang membutuhkan upaya-upaya penajaman dengan melakukan pembacaan-pembacaan teoretis tertentu, melalui pendekatan-pendekatan yang lebih tepat, dalam rangka menjelaskan secara filosofis gejala fundamentalisme islam yang ada di-Mesir.

\section{Pencandraan Teoretis Gerakan Politik Ikhwan al Muslimin di Mesir}

Ada dua hal yang menarik untuk diamati secara teoretis menyangkut karakteristik gerakan Ikhawan al Muslimin di Mesir. Pertama: Faktor yang melatarbelakangi gerakan Ikhwan, sehingga tetap bersikap konsisten, gigih dan rigid dalam "mengembangkan misi organisasinya meski dihadapkan pada tantangan yang amat. pahit. Menurut pandangan John L. Esposito fenomena ini diistilahkan dengan gerakan militansi yang sesungguhnya. Ia merupakan gerakan progresif dan reaksioner. Komitmen ini muncul dari persoalan intern yang ada dalam diri mereka sendiri, yaitu usaha untuk memberantas berbagai bentuk kejahatan dengan menerapkan kebaikan berdasarkan syari'ah Islam (Esposito, 1990: 33-34). Kedua: faktor yang menyebabkan gerakan ini sulit terakomodir di kalängan penguasa maupun sebagian kalangan masyarakat tertentu. Sulitnya gerakan ini terakomodir dikalangan penguasa menurut J.L.Esposito adalah karena kelompok ini sangat mengurung.dirinya. Menganggap apa yang ada diluar dirinya selalu di curigai, lebih-lebih isu modernisasi yang dianggap 'ala ke Barat-baratan (Esposito, 1990: 33-34). Kelompok ini ingin menerapkan Islam secara total, ridak terbatas pada persoalan kerohaniahan saja tetapi juga pada dimensi-demensi sosial lainnya, namun dalam kenyataan sosial, praktek dari kelompok ini selalu terikat oleh batas-bataslingkaran primordial pemahaman keagamaan yang terkesan sangat eksklusif. Dengan demikian jargon gerakan

Ulul Albab, Vol. 10, No. 1, 2009 
ini kurang bisa merelevansikan antara teori dan praktik, karena tidak jarang terjadi anomali-anomali antara keduanya.

Praktek politik Islam yang banyak dilakukan oleh kelompok fundamentális Ikhwan sepanjang ini senada dengàn pembacaan J.L. Esposito. Kèrap kali konsep dan teori politik yang dikonsepsikan berjalan secarà turun-temurun dan berkesan menjadi barang inati, yang tidak mengenal kompromi. Kegagalan gerakan ikhwan bisa dinilai karena konsep teori politiknya yang dibangun tanpa mengenal kompromi, lebih-lebih dari kalangan Barat.

Untuk méngamati lebih rinci dua persoalan di atas, ada dua pendekatan teoretis yang relevan untuk membaca sekaligus menjelaskan gejala fundamentalis gerakan Ikhwan al Muslimin tersebut, yaitu dengan pendekatan teori politik Islam dan teori moral.

Para pengamat Islam banyak menulis sejumlah buku tentang teori politik Islam dalam beberapa topik, seperti sistem pemerintahan, hubungan pemerintah dengan rakyat, jenis kekuasaan dalam Islam. Sekalipun sudah cukup banyak tulisan mengenai topik itu, ternyata masih saja menyisakan beberapa celah pembahasannya. Kebanyakan celah pembahasan itu disebabkan karena pemikiran mereka banyak terjebak pada pemandangan idealis, tanpa melihat realitas dan bagaimana cara mengaktualisasikan bentuk idealisme itu. Akhirnya banyak gagasan-gagasan yang hanya bertengger di atas menara gading secara sakral, tanpa pernah menyentuh bumi realitas (ath Thahhan, 2000: 47). la tidak diformulasi dengan kemasan modern dan konsep yang cermat sehingga tidak kunjung mampu menjawab berbagai persoalan yang muncul dari waktu ke waktu.

Sebagian mereka telah berusaha untuk mengkaji konsep Islam tentang sistem pemerintahan dengan berpatokan pada eksperimen awal, dengan pandangan bahwa ia merupakan eksperimen paripurna dan konstitusional yang final, tanpa memperhatikan karakter eksperimannya, bagaimana kondisi politik, sosial dan historis yang menjadi objek instrumennya. Menurut Ath Thahhan kebutuhan yang sangat mendesak untuk umat Islam kini adalah

Ulul Albab, Vol. 10, No. 1, 2009 
format teori politik Islam yang integral, yang dapat dikaji dan di reformasi (ath Thahhan, 2000: 48).

Idealitas teori politik Islam menurut Ath Thahhan bertolak dari kaedahkaedah umum, yaitu kebebasan, kesetaraan, keadilan dan supremasi hokum, juga adanya konsistensi terhadap prinsip pemilihan pemimpin, dan bahwa pemerintah adalah pelaksana hukum dan perundang-undangan, pelindung agama dan bertanggung jawab terhadap rakyat. Di antara hak rakyat adalah memberi nasihat, mengevaluasi, memecat, dan menggantikannya jika diperlukan. Sistem politik harus tegak di atas prinsip syura, dan syura menjadi sesuatu yang harus ditegakkan oleh penguasa.

Sistem politik Islam harus memuat persepsi yang jelas tentang kebebasan politik, aktifitas politik, partai-partai politik, kritik politik, kebebasan pers, kedudukan kaum wanita, sistem sosial, sistem ekonomi, pemerataan kekayaan serta independensi peradilan (ath Thahhan, 2000: 49). Atas dasar itu, para pemikir Islam menurur Ja'far Abdur Razaq harus terpanggil untuk memberikan kontribusi dalam menegakkan sistem politik Islam yang akomodatif dan dialogis bagi kepentingan umat muslimin, peradaban dan sejarahnya.

Para pemikir Islam idealnya mampu memberikan jawaban-jawaban atas pertanyaan-pertanyaan berikut secara tepat, antara lain :

Apakah sistem politik Islam merupakan sistem politik yang khas dan independen, tegak di atas prinsip iman kepada Allah, yang pandangannya lahir dari persepsinya tentang alam, manusia, kehidupan dan sekaligus menolak prinsip lain.

Sampai dalam batas mana sistem politik Islam dengan sistem politik lain? Mungkinkah memanfaatkan berbagai pengalaman kemanusiaan yang beraneka ragam, atau justru menganggap hal itu sebagai sistem yang cacat dalam politik Islam.

Apakah syura itu? Dan bagaimana aplikasinya di tengah umat, pelaksanaan konsep dan pemilihan pemimpin?

Apa syarat kepala negara dan bagaimana ia dipilih? Apakah sistem

Ulul Albab, Vol. 10, No. 1, 2009 
kepemimpinannya seumur hidup? Bolehkah dipecat? Apa hak dan kewajibannya?

Apakah sumber kekuasaan itu? Dan bagaimana prinsip kedaulatan dalam negara?

Bagaimana penjelasan tentang tiga kekuasaan yang terpisah, legislatif, eksekutif dan yudikatif?

Semua topik di atas dalam teori politik Islam harus jelas dan tepat. Di atas prinsip-prinsip inilah sistem politik Islam ditegakkan, dengan memanfaatkan setiap hikmah yang ada di muka bumi ini siapapun pemiliknya dan dalam waktu yang sama juga bertolak dari aksioma-aksioma Islam yang telah ditetapkan oleh syari'ah yang suci.

Jika gerakan fundamentalis Ikhwan di baca dari perspektif teori politik Ath Thahhan ini, banyak kita temukan beberapa titik lemah. Titik lemah itu bisa kita lihat pada kurang akomodatifnya praktek maupun teori politik yang di terapkan oleh gerakan Ikhwan. Disamping itu konsep politiknya berkesan dikonstruksi secara emosional tanpa bermaksud memanfaatkan setiap hikmah yang ada di muka bumi ini, siapapun pemiliknya, sesuai dengan perkembangan zamannya. Dua persoalan yang mendasar inilah yang menjadi penyebab prinsipal gagalnya gerakan Ikhwan tersebut, meski dari pihaknya belum dianggap sebagai bentuk kegagalan yang nyata.

Disamping teori politik Islam yang telah disampaikan oleh Ath Thahhan di atas, gerakan fundamentalis Ikhwan ini juga tepat sekali jika di dekati dengan teori moral Imanuel Kant. Dalam pandangan Kant, moral itu terdiri dari moral apriori dan moral pure. Yang pertama lebih memiliki ketergantungan dengan pengalaman yang sudah ada, sesuatu yang sudah dititahkan (teleologis finalistik), sementara yang kedua berupaya untuk mengandaikan semua keputusan yang hendak memberi kita pada pengalaman baru (Aiken, 2002: 27 dan Muhni, 1994: 37).

Menurut E. Durkheim ada dua teori moral yang berlaku. Kaum spiritualis seperti Kant menggambarkan pengalaman moral sebagai fakta khusus dan bersifat transenden, barang jadi. Mereka menganggap manusia 
bukan sebagai anggota alam. Di pihak lain naturalistik sebagai suatu kemungkinan. Ketika Durkheim dihadapkan pada dua teori itu ia kemudian memilih jalan tengah dan berusaha untuk menghapus jarak antara manusia dan alam. Dan karena itu memungkinkan lahirnya penjelasan moral dan religi secara sosiologis (Aiken, 2002: 27). Dengan demikian moral menurut Durkheim hanya akan hidup dalam konteks sosial. Moralitas dan segala bentuknya tidak akan hidup kecuali dalam masyarakat (Muhni, 1994: 37). Jika hal ini dikaitkan dengan agama, maka agama pun menurut Durkheim juga memiliki peran yang sama, yaitu tidak bisa dielakkan dalam kehidupan masyarakat. Durkheim sendiri sebagai seorang yang ateis melihat dan mengakui pentingnya religi dalam hubungannya dengan tingkah laku moral (Muhni, 1994: 45).

Moral dan religi tidak hanya dimiliki oleh kelompok fundamentalis, yang kerap memposisikan agama hanya berada pada ranah teologis dan kurang menyentuh pada wilayah sosiologis. Sikap pemahaman (moral) yang sangat apriori, bersifat transendental dan kurang menghayati pada komunitasnya, acapkali tampil menjadi hamba yang memposisikan dirinya paling dekat, paling suci, paling benar dan paling agamis dan moralis. Kelompok inilah dalam pandangan Durkheim sangat membahayakan. Maka teori Durkheim yang mengatakan bahwa suatu tempat yang konon diklaim sangat agamis disitu pula dimungkinkan rawan terjadi kekerasan dan konflik menjadi sangat relevan. Inilah corak sikap pemahaman dan penerapan keagamaan mayoritas kelompok fundamentalis, termasuk gerakan Ikhwan. Karena sikap pemahamannya yang sangat apriori, maka kelompok ini menjadi sangat eksklusif, merasa paling benar.

\section{Simpulan}

Dari penjelasan di atas dapat ditarik kesimpulan bahwa gerakan Ikhwan merupakan gerakan fundamentalisme Islam yang menjadikan kendaraan politik sebagai alat mencapai tujuan misi organisasinya. Gerakan ini muncul sebagai reaksi atas bangkitnya pemerintahan sekuler, yang menggeser praktek syari'ah islam dalam pelaksanaan pemerintahannya. 
Fakta ini telah menyalakan semangat revolusioner gerakan Ikhwan untuk berjuang menegakkan syari'ah Islam. Dalam praktek untuk mensukseskan visi-misinya, gerakan ini menempuh dua jalan pendekatan, baik melalui diplomasi, maupun sikap tegas dan konsisten terhadap para penguasa yang tidak mengakomodasi kepentingannya.

Kegagalan Ikhwan dalam mencapai tujuannya, terutama disebabkan mereka kurang mampu mengadaptasikan misi-misinya di hadapan penguasa secara umum. Hal ini disebabkan karena kurang akomodatifnya gerakan ini terutama terhadap penguasa, lebih-lebih mereka yang ada di luar kelompoknya. Fakta sejarah telah membuktikan, bahwa sejak jama'ah ini berdiri, kelompok ini tidak pernah mendapat dukungan mayoritas dari umat Islam pada umumnya dan pemerintah pada khususnya. Hal ini bisa kita saksikan juga bahwa dibalik kedekatan mereka dengan penguasa ternyata hanya merupakan rekayasa politik penguasa untuk menghancurkan gerakan ini. Sehingga sejak awal bisa dinilai bahwa gerakan Ikhwan dalam kenyataannya hanya tampil sebagai kelompok oposan pemerintah hingga saat ini. Eksklusifitas gerakan ikhwan pada hakikatnya merupakan penyebab prinsip gagalnya gerakan tersebut. 


\section{Daftar Pustaka}

Abdalla, Ulil Abshar. 2003. Menyegarkan Kembali Pemahaman Islam, dalam Islam Liberal dan Fundamental. Yogyakarta: Elsaq Press.

Aiken, Henry D. 2002. Abad Ideologi. Terjemahan oleh Sigit Djatmiko. Yogyakarta: Yayzsan Bentang Budaya.

Al Husaini, Ikhwan al Muslimin. 1984. Jakarta: Grafiti Press. hal. 9.

Amin, Mashur. 1993. Dialog Pemikiran Islam dan Realitas Empirik.

Yogyakarta: LKPSM NU DIY.

Ath Tahhan, Musthafa Muhammad. 2000. Rekonstruksi Pemikiran Menuju Gerakan Islam Modern. Terjemahan oleh Salafuddin. Solo: Era Intermedia.

Azra, Azyumardi. 1996. Pergolaan Politik Islam: Dari Fundamentalisme, Modernisme hingga Post-Modernisme. Jakarta: Paramadina.

Esposito, John L. 1990. Islam dan Pembangunan. Jakarta: Rineka Cipta.

Hino, Dilip. 1989. Islamic Fundamentalism. London: Poladin Book.

Jamilah, Maryam. 1993. Para Mujahid Agung. Terjemahan oleh Hamid Lutfi. Bandung: Mizan.

Mahmud, Ali Abdul Halim. 1997. Ikwan al Muslimin Konsep Gerakan Terpadu. Terrjemahan oleh Syafril Halim. Jakarta: Gema Insani Press.

Martin, Richard C. 1985. Approaches To Islam in Religious Studies. USA: The University of Arizona Press.

Muhni, Djuretna A. Imam. 1994. Moral dan Religi: Menurut Emile Durkheim dan Henry Bergson. Yogyakarta: Kanisius.

Mujahidin, Ahmad. 2003. Fundamentalisme Sebagai Fenomena Politik: Analisis terhadap Geralan Ikhwan al Muslimin. Jurnal Studi Keislaman, Maret.

Mutawalli. 2003. Islam Fundamentalis Sebagai Fenomena Politik. Jurnal Studi Keislaman, Maret. 
Tibi, Bassam. 1998. The Challenge of Fundamentalism: Political Islam and The New World Disorder. Berkeley: University of California Press.

Sahat, Ahmad. 1993. Roger Garaudy Tentang Fundamentalisme. Jurnal Islamika, No. 1 Juli-September.

Sihbudi, Riza. 1991. Bara Tinur Tengah. Bandung: Mizan.

Ulumul Quran. 1989. Jurnal Ilmu dan Kebudayaan. Volume II.

Ulul Albab, Vol. 10, No. 1, 2009 